\title{
PEMODELAN CALON GURU FKIP UNMAS DENPASAR MELALUI LESSON STUDY BERBASIS HABIT FORMATION LEARNING SYSTEM
}

\author{
Dewa Gede Agung Gana Kumara, Nengah Dwi Handayani \\ Fakultas Keguruan dan Ilmu Pendidikan Universitas Mahasaraswati Denpasar \\ email:dewagana11@gmail.com
}

\begin{abstract}
ABSTRAK
Tujuan penelitian ini adalah untuk mengetahui tingkat kompetensi siswa SMP seni ukir Tangeb melalui lesson study berbasis Habit formation Learning System yang melibatkan para guru, dosen dan mahasiswa calon guru. Metode penelitian ini menggunakan pendekatan tindakan kelas melalui model lesson study. Rentangan proses penelitian menggunakan dua siklus. Instrumen yang digunakan dalam pengumpulan data berupa penilaian praktek mengajar, chararacter check list, angket dan lembaran pengamatan partisipasi. Keefektifan pendekatan dapat di analisis sejauh mana nilai rerata 38 siswa yang dikumpulkan secara acak setiap siklus meningkat dari nilai tes awal seteleh lesson studyditerapkan. Indikator keberhasilan penelitian atau target luaran penelitian ini dimana $80 \%$ peserta didik meraih nilai rerata di atas ketuntasan minimal yaitu; 75. Dari rentangan PAP prestasi belajar siswa yang mencapai kreteria tinggi sebanyak 21 orang sedangkan yang kreteria sedang sebanyak 17 orang. Dari sikap belajar siswa dapat diketahui sebanyak 30 siswa (86\%) aktif, 33 (87\%) siswa yang kooperatif dan siswa bertanggung jawab sebanyak 36 siswa (94\%). Dari hasil ini dapat dikatakan bahwa kemampuan siswa kelas VII SMP Seni Ukir Tangebdalam sikap belajar, pengetahuan dan ketrampilan menulis bahasa Inggris dalam kategori tinggi dan sikap membudaya diatas $50 \%$. Dengan demikian lesson study berbasis pembentukkan kebiasaan ini dapat meningkatkan kemampuan bahasa Inggris siswa kelas VII SMP Seni Ukir dan sikap belajar mereka lebih berkarakter
\end{abstract}

Kata kunci: pembelajaran, pengajaran, model lesson study, komunikatif

\section{ABSTRACT}

The purpose of this study was to determine the level of students' competence of SMP Tangeb majoring in sculpture through the lesson study Habit-based formation Learning System involving teachers, lecturers and prospective teachers. This research method used classroom action approach through lesson study. The research process spanned two cycles. Instruments used in data collection included assessment of teaching practice, chararacter check list, questionnaire and participant observation sheet. The effectiveness of the approach could be analyzed to what extent was the average score of 38 students collected randomly in each cycle increased from the initial test score after the lesson was applied. The indicator of research success or research outcome target was where $80 \%$ of students achieved the average value above the minimal mark that was 75 . From the PAP range of students' achievement, students that reached the high criteria were 21 people while the moderate criteria were 17 people. From students' learning attitude could be seen that 30 students (86\%) were active, 33 (87\%) were cooperative and students that were responsible were 36 students (94\%). From this result, it could be said that the ability of VII grade students of SMP Seni Ukir Tangeb in attitudes of learning, knowledge and writing skills of English was in 
high category and above entrepreneurial attitude that was 50\%. Thus the lesson study based on the formation of this habit could improve the English language skills of VII students of SMP Seni Ukir and their attitude in learning was more characteristic.

Keywords: learning, teaching, lesson study model, communicative

\section{PENDAHULUAN}

Mutu pendidikan sangat tergantung pada kinerja para guru dalam mengembangkan potensi peserta didik. Keprofesionalan guru-guru mata pelajaran memegang peranan yang sangat penting bagi kemajuan pendidikan nasional sehingga dalam proses menempuh kualifikasi pendidikan calon guru di FKIP harus secara intensif dan kreatif menimba dan mengembangkan ilmu dalam bidang pengajaran. Undang-undang no 14 tahun 2005 tentang guru dan dosen telah menyatakan bahwa guru adalah pendidik profesional dengan tugas utama mendidik, mengajar, membimbing, mengarahkan, melatih, menilai, dan mengevaluasi peserta didik pada pendidikan anak usia dini jalur pendidikan formal, pendidikan dasar, dan pendidikan menengah. Jadi para calon guru harus memiliki kecerdasan, termasuk kecerdasan pegagogik dan kecerdasan sosial.

Dalam prosesnya, mahasiswa sulit menyerap pengetahuan dari dosennya tetapi lebih memahami ketika terlibat langsung dalam pengajaran. Menurut Davis (2003) mahasiswa calon guru lebih banyak belajar dari bagaimana mereka diajar oleh para dosennya dan bukan dari apa yang dipaparkan dosen tentang cara mengajar yang baik. Semestinya para dosen memberikan contoh-contoh nyata tentang bagaimana melakukan pembelajaran, partisipasi sebagai observer atau mengamati rekaman video untuk meningkatkan kemampuan mahasiswa calon guru dalam menyampaikan materi. Sementara menurut Hinduan (2005:8) program pelatihan dalam pendidikan (in-service training) yang selama ini dilaksanakan memisahkan metode mengajar dengan materi. Pembahasan tentang metode atau penerapan model dan materi pembelajaran biasanya kurang disertai dengan contoh nyata yang berkaitan kehidupan sehari-hari. Materi pelajaran yang dibahas sangat akademis dan lepas dari konteks pembelajaran. Kondisi ini menyebabkan calon guru kesulitan dalam menerapkan apa yang diperolehnya dalam pendidikan atau pelatihan.

Dalam teori belajar, pembelajaran merupakan akibat adanya interaksi antara stimulus dan rensponse (Slavin, 2000: 143). Seseorang dianggap telah belajar sesuatu jika dia dapat menunjukan perubahan perilakunya. Salah satu keterampilan penting yang perlu dimiliki calon guru adalah keterampilan membuka pelajaran, mengaktifkan siswa, dan mentranfer materi pelajaran. Membuka pelajaran seringkali diartikan hanya sebagai sejumlah kegiatan saat guru memasuki ruang kelas. Kegiatan membuka pelajaran mempunyai beberapa komponen, yaitu: menarik perhatian siswa, memberikan motivasi, dan memberikan acuan.

Namun, permasalahan yang sering dijumpai oleh calon guru FKIP Unmas Denpasar adalah perencanaan pembelajaran, penguasaan kelas, pemahaman materi ajar dan pemetaan kemampuan siswa. Sehingga hasil dari kuliah micro teaching dan PPL berlalu tanpa dampak yang berarti bagi 
siswa di sekolah tempat praktikum. Salah satu faktor penyebabnya adalah metode pembelajaran dan pemodelan sikap dosen dalam kelas. Metode dosen belum mampu merangsang pengetahuan peserta didik sehingga mereka tidak bisa mengasosiasikan pengetahuan dalam bahasanya dengan tugas yang diberikan. Dosen seharusnya mencari terobosan penerapan metode yang inovatif dalam proses ketrampilan menulis dan pemodelan sikap sebagai tuntunan peserta didik. Salah satu metode yang tepat adalah penerapan model lesson study berbasis habit formation learning system

Lesson study merupakan sebuah model kegiatan pelatihanpengajaran yang dilaksanakan oleh guru maupun calon guru. Model ini diketahui sebagai rahasia keberhasilan Jepang dalam peningkatan kualitas pendidikannya (Stigler \& Hiebert, 1999: 109). Prinsip utama lesson study adalah peningkatan kualitas pembelajaran secara bertahap dengan cara belajar dari pengalaman sendiri dan orang lain dalam konteks lingkungan terdekat. Lesson Study menitik beratkan learning to know menuju learning to dodan mengarah pada learning to live together. Pelaksanaan pengajaran oleh calon guru FKIP melalui lesson study dengan empat tahapan dengan materi yang berkaitan kehidupan sehari-hari, yaitu: perencanaan (PLAN), praktek (DO), pengamatan (OBSERVATION) dan /kritikan (REFLECTION). Pembelajaran yang diberikan oleh calon guru pada kegiatan praktikum dapat menanamkan konsep dasar pemahaman dan aplikasi kedalam kehidupan nyata peserta didik. Dengan demikian, mereka mendapatkan pengalaman belajar yang tidak hanya dapat meningkatakan prestasinya tetapi juga berdampak pada kehidupan mereka kelak. Lesson Study bukanlah hanya bermanfaat bagi siswa namun juga bagi pengembangan profesionalisme calon guru yang bersangkutan. Oleh karena itu "Lesson Study" bisa dijadikan alternatif terhadap program pelatihan guru yang telah ada.

Berdasarkan pemaparan di atas, penelitian ini akan menitik beratkan pada proses ketrampilan para calon guru, dosen peneliti FKIP Unmas Denpasar dan para guru bahasa Inggris di sekolah dalam meningkatkan kompetensi mengajar melalui model lesson study berbasis habit formation learning system. Pelaksanan penelitian ini diharapkan dapat memberikan informasi lebih detil tentang hasil dan dampak, baik bagi calon guru yang bersangkutan maupun bagi keberlangsungan pendidikan yang berkualitas.Untuk itu, pemecahan masalah yang ditawarkan berupa tindakan dengan penerapanlesson studyberbasishabit formation learning system.Jadi masalah dan pemecahan dalam penelitian ini dapat dirumuskan sebagai berikut: Bagaimanakah kemampuan bahasa Inggris siswa VII SMP seni Ukir Tangeb setelah model Lesson study berbasis habit formation learning system diterapkan?Bagaimanakah sikap siswa didik setelah diajarkan oleh pemodelan calon guru FKIP Unmas Denpasar melalui Lesson study berbasis habit formation learning system ?

Tujuan penelitian adalah Pelaksanan penelitian ini untuk mengetahui perubahan proses pengajaran yang dilaksankan oleh calon guru FKIP Unmas Denpasar melalui model lesson study berbasis daily lfe learning systemdanmengkajiperubahan sikap belajar peserta didik kelas VII SMP seni Ukir Tangeb yang jujur, bertanggung jawab dan bekerja sama dalam menulis bahasa Inggris setelah model lesson study berbasis daily life learning system.

Terdapat beberapa penelitian yang relevan dengan penelitian yang dilakukan sebagai acuan empiris. Pertama adalah Terdapat beberapa penelitian relevan dengan penelitian ini yang digunakan sebagai 
pustaka acuan atau acuan empiris. Penelitian pertama adalah penelitian yang dilakukan oleh Insih Wilujeng (2012) dengan judul Model Integrated Science Berbasis Local Technology and Local Wisdom untuk Merintis Terwujudnya Outdoor Learning System. Model ini dibuat dengan setting pembelajaran di luar ruangan mampu mewujudkan hakikat dari pembelajaran IPA secara terpadu, bersifat tematik serta mampu mengatasi permasalahan para generasi muda tentang melemahnya moral (penghargaan terhadap teknologi, budaya dan kearifan lokal) serta perwujudan sumber dan lingkungan belajar di masyarakat.

Penelitian kedua dilaksanakan oleh Ari Widodo dkk dengan judul "Peranan lesson study dalam peningkatan kemampuan mengajar mahasiswa calon guru". Penelitian yang dilaksanakan bertujuan untuk mengetahui peningkatan kemampuan mengajar dari guru praktek dengan leson studi berbasis penggunaan kamera vidio. Berdasarkan pengamatan angket, iklim emosi mengajar para guru praktek cukup bagus. Sementara pengalaman belajar dengan lesson study membuat mereka memahami dan memberikan pandanagan yang sangat berarti dalam usaha meningkatkan kompetensi mengajar.

\section{METODE PENELITIAN}

Penelitian ini diselenggarakan di di SMP UkirTangaeb yang berlokasi di $\mathrm{Br}$. DelodPempatan, Tangeb, Mengwi. Subjek penelitian ini adalah murid kelas VII yang memiliki 38 murid; 20 laki-laki dan 18 perempuan. Kelas ini dipilih karena 80 persen dari mereka memiliki pengetahuan dan ketrampilan bahasa Inggris yang rendah dan sikap belajar yang memprihatinkan. Kondisi belajar tidak kondusip dan perilaku tidak jujur. Sesuai karakter permasalahan, tujuan atau target yang ingin dicapai, penelitian ini mengacu pada penelitian pembelajaran pada latar kelas (PTK). Penelitian tindakan dapat diartikan sebagai sebuah studi yang objektif, sistematis, dan terkontrol untuk mengamati efektifitas dari tindakan. Tindakan perbaikan proses belajar telah dilaksanakan melalui bebera siklus yang masing-masing terdiri tiga sesi pembelajaran. Masing-masing sesi memiliki empat langkah yang saling berhubungan, yaitu: perencanaan, tindakan, pengamatan dan perenungan.

Tiga jenis instrumen yang digunakan untuk mengumpulkan data penelitian adalah tes, cheklist sikap belajar, lembaran pengamatan dan angket dengan metode pengamatan keaktifan partisipasi. Ada dua kelompok tes yang digunakan berdasarkan perbedaan fungsinya, yaitu: tes awal yang digunakan untuk mengukur kemampuan awal siswa dalam menulis bahasa Inggris dan tes akhir untuk engukur kemampuan menulis setelah penerapan treatment diakhir setiap siklus. Sementara checklist sikap belajar berfungsi untuk mengetahui sikap nyata siswa dalam proses belajar mengajar yang Data dilaksanakan sebelum tindakan diterapkan dan sesudah tindakan dilaksanakan di akhir siklus. Untuk mengetahui tingkat partisipasi, lembaran pengamatan untuk mengetahui tingkat keaktifan partisispasi dikerjakan oleh guru, dosendanmahasiswacalon guru yang mengajar dan angket untuk mengetahui respon selama metode belajar diberikan kepada peserta didik diakhir siklus.

Data yang dikumpulkan berupa skor perolehan (pre-test dan post-tets) dianalisis dengan pendekatan statististik deskriptif, yaitu dengan menentukan jumlah nilai ratarata, median dan mode. Hasil penelitian ini tidak dapat digeneralisasi karena kondisi kelas VII heterogen. Skor yang diperoleh mencerminkan sikap belajar, pengetahuan dan kemampuan siswa SMP Seni UkirTangebdalam 
kompotensdanperformansibahasa Inggris. Jadi terdapat tiga nilai rata-rata dan prosentase respon siswa terhadap tindakan yang diberikan, yaitu:
a. Nilai rata-rata kompetensi sikap belajar, pengetahuan, dan ketrampilan sebelum treatmen diberikan (precycle)
b. Nilai rata-rata kompetensi sikap belajar, pengetahuan, dan ketrampilan menulis siswa setelah lessonstudy
c. Nilai rata-rata kompetensi sikap belajar, pengetahuan, dan ketrampilan Bahasa Inggris
d. Prosentase respons siswa setelah strategi pembelajaran dilaksanakan

\section{HASIL DAN PEMBAHASAN}

Keberhasilan dan efektifitas model pembelajaran sangat ditentukan oleh out put dari proses tindakan dalam proses belajar mengajar. Peneliti memfokuskan karakterisasi peningkatan kemahiran bahasa Inggris melalui lesson study pada teks Kegiatan pembiasaan sehari-hari. Penelitian ini menggunakan pendekatan kuantitatif dengan analisis deskriptif karena data yang akan disajikan dalam bentuk angka-angka, gambar dan rangkaian kalimat. Data yang digunakan untuk mengukur kemampuan bahasa Inggris siswa kelas VII SMP seni Ukir Tangeb menunjukan tiga kompetensi mereka, yaitu: sikap, pengetahuan dan ketrampilan. Data tersebut diperoleh dengan menggunakan lembaran observasi, tes awal, tes awal akhir, dan angket berstruktur dengan 10 pernyataan yang menyangkut proses tindakan. Tes terdiri dari tes diagnotis, tes unjuk kerja dan portopolio. Dari hasi pre tes, dapat diketahui bahwa kemampuan siswa masih kurang, yaitu 63, sementara sikap mereka masih kurang disiplin, dan tidak bertanggung jawab. Untuk itu telah dilakukan tindakan pembelajaran rekontruksi lesson studypengumpulan data dalam beberapa siklus.

\section{Siklus I}

Berdasarkan hasil refleksi pada studi awal di atas, siklus 1 telah dilaksanakan dalam 2 sesi pertemuan dengan menerapkan model karakter melalui lesson studyteks dari cerita Kegiatan pembiasaan sehari-hari. Di masing-masing sesi terdapat 4 langkah penerapan, yaitu: perencanaan, tindakan, pengamatan dan refleksi. Semua tindakan dalam penerapan model pembelajaran, pengamatan dan refleksi direncanakan secara ditail, yaitu penyusunan RPP, pemyusunan soal, penyediaan lembaran pengamatan dan angket, pengumpulan materi, dan rancangan koreksi.

Dalam pelaksanaan penelitian, peneliti melibatkan siswa dengan mengelompokan mereka kedalam beberapa group yang terdiri dari 5 siswa. Mereka membaca teks kegiatan sehari-hari dan mencari pesan moral cerita tersebut. Selanjutnya menterjemahkan teks tersebut kedalam bahasa Indonesia. Siswa kemudian mencocokan dan memilih perilaku dari cerita tersebut dengan perilaku mereka selama ini. Terakhir semua siswa menterjemahkan teks kedalam bahasa Inggris dan mencari kata-kata sifat yang cocok dengan karakter mereka. Pada saat yang bersamaan, guru dan anggota peneliti mengamati sikap belajar siswa. Kemudian peneliti memeriksa tugas dan bersama siswa mengkonstruksi terjemahan tersebut. Diakhir tindakan peserta didik diberikan pos tes yang mengukur sikap, pengetahuan dan ketrampilan menulis bahasa Inggris. Waktu yang diberikan dalam mengerjakan hanya satu jam. Semua hasil pos tes tersebut diperiksa, dinilai dan dianalisis untuk mendapatkan nilai rata-rata.

Untuk memberikan informasi lengkap tentang keadaan awal prestasi 
siswa, maka ringkasan hasil tes awal tersebut dianalisis dan disajikan dalam tabel berikut.

Tabel 1. Ringkasan hasl Pretest siswa

\begin{tabular}{l|c}
\hline Jumlah Nilai & 2654 \\
\hline Rata-rata & 70 \\
Median & 72 \\
Mode & 72 \\
KKM & 75 \\
Jumlah siswa dengan kreteria kurang & 5 \\
Jumlah siswa dengan kreteria sedang & 33 \\
Prosentase Ketuntasan Belajar & $19 \%$ \\
\hline
\end{tabular}

Untuk menguatkan informsi tentang perubahan sikap siswa, peneliti mengamati sikap belajar mereka dalam pelaksanaan tugas berkelompok dan individu, maka semua siswa diamati dengan menggunakan lembaran Instrumen observasi terstruktur. Hasil observasi ini kemudian dianalisis tingkat prosentase siswa yang aktif, kooperatif dan bertanggungjawab, seperti yang disajikan dalam tabel berikut.

Tabel 2. Prosentase sikap belajar siswa dalam penerapan Lesson studypada siklus 1.

\begin{tabular}{|c|c|c|c|}
\hline No & $\begin{array}{c}\text { Komponen yang } \\
\text { Diamati }\end{array}$ & Jumlah & $\%$ \\
\hline 1 & Siswa Aktif & 20 & $53 \%$ \\
\hline 2 & Siswa Kooperatif & 25 & $66 \%$ \\
\hline 3 & $\begin{array}{l}\text { Siswa yang dapat } \\
\text { menyelesaikan tugas }\end{array}$ & 30 & $79 \%$ \\
\hline
\end{tabular}

\section{Siklus II}

Berdasarkan hasil belajar pada siklus I di atas, maka peneliti menyusun refleksi tindakan karena masih banyak siswa yang belum mencapai ketuntasan belajar minimal. Ini berarti sikap, pengetahuan dan ketrampilan mereka perlu ditingkatkan dan memberikan solusi pada permasalahan yang mereka hadapi. Ada beberpa pokok perbaikan dalam ketiga aspek kompetensi tersebut, yaitu: menggunakan media serta memberikan motivasi pada siswa yang masih remedi. Selanjutnya tindakan berikut telah dilaksanakan pertemuan dalam 2 sesi pada siklus II dengan menerapkan model karakter melalui lesson studyteks dari cerita kegiatan pembiasaan sehari-hari. Di masing-masing sesi terdapat 4 langkah penerapan, yaitu: perencanaan yang direvisi, tindakan, pengamatan dan refleksi.

memberikan latihan tambahan, menyederhanakanpenjelasan,

Dalam pelaksanaan penelitian, peneliti melaksanakan strategi yang sama tetapi menekan beberapa hal yang berkaitan dengan pokok perbaikan yang telah dirancang Penelitian ini melibatkan siswa dengan mengelompokan mereka kedalam beberapa group yang terdiri dari 5 siswa. Mereka membaca teks kegiatan sehari-hari dan mencari pesan moral cerita tersebut. Selanjutnya menterjemahkan teks tersebut kedalam bahasa Indonesia. Siswa kemudian mencocokan dan memilih perilaku dari cerita tersebut dengan perilaku mereka selama ini. Terakhir semua siswa menterjemahkan teks kedalam bahasa Inggris dan mencari katakata sifat yang cocok dengan karakter mereka. Pada saat yang bersamaan, guru dan anggota peneliti mengamati sikap belajar siswa. Kemudian peneliti memeriksa tugas dan bersama siswa mengkonstruksi terjemahan tersebut. Diakhir tindakan peserta didik diberikan pos tes yang mengukur sikap, pengetahuan dan ketrampilan menulis bahasa Inggris. Waktu yang diberikan dalam mengerjakan hanya satu jam. Semua hasil pos tes tersebut diperiksa, dinilai dan dianalisis untuk mendapatkan nilai rata-rata. Setelah ditemukan nilai rata-rata siswa, peneliti 
kemudian menghitung jumlah siswa yang sudah mencapai KKM.

Untuk memberikan informasi lengkap tentang prestasi siswa, maka ringkasan hasil sesi 3 dan sesi 4 di siklus II tersebut dianalisis dan disajikan dalam tabel berikut.

Tabel 3. Ringkasan hasl Post test siklus II siswa VII SMP seni Ukir Tangeb

\begin{tabular}{ll}
\hline Jumlah Nilai & 3045 \\
Rata-rata & 80,2 \\
Median & 80 \\
Mode & 80 \\
KKM & 75 \\
Jumlah siswa kreteria sedang & 17 \\
Jumlah siswa kreteria tinggi & 21 \\
Prosentase Ketuntasan Belajar & $81 \%$ \\
\hline
\end{tabular}

Berdasar ringkasan hasil belajar studyditerapkan, sikap, pengetahuan dan ketrampilan menulis siswa meningkat. Ini bisa dilihat dari nilai rata-rata siswa dan prosentase ketercapaian ketuntasan belajar. Untuk ketiga kompetensi tersebut, subjek penelitian paling tidak harus mencapai ketuntas belajar KKM, yaitu nilai 75 . Indikator keberhasilan penelitian ini ditentukan dari prosentase pencapaian KKM telah mencapai lebih dari $80 \%$ dari 40 siswa. Sehingga model rekontruksi lesson studysangat efektif dalam tingkat pemahaman, kemampuan menulis bahas Inggris dan perubahan sikap belajar peserta didik. Sementara untuk perkembangan perubahan karakter dan sikap belajar, penelitian ini akan dihentikan jika sikap siswa sudah memenuhi lebih dari prosentase membudaya konsisten minimal, yaitu: $50 \%$, seperti yang disajikan dalam tabel berikut.
Tabel 4. Prosentase sikap belajar siswa dalam penerapan Lesson studypada siklus II

\begin{tabular}{llll}
\hline No & $\begin{array}{l}\text { Komponen yang } \\
\text { Diamati }\end{array}$ & Jumlah & \% \\
\hline 1 & Siswa Aktif & 30 & $86 \%$ \\
2 & $\begin{array}{l}\text { Siswa Kooperatif } \\
\text { Siswa yang dapat }\end{array}$ & 33 & $87 \%$ \\
3 & $\begin{array}{l}\text { menyelesaikan } \\
\text { tugas }\end{array}$ & 36 & $94 \%$ \\
\hline
\end{tabular}

Untuk mengetahui sikap belajar dan efektifitas metode melalui lesson studymelalui kegiatan pembiasaan seharihari berikut dapat disajikan dalam bentuk grafik.

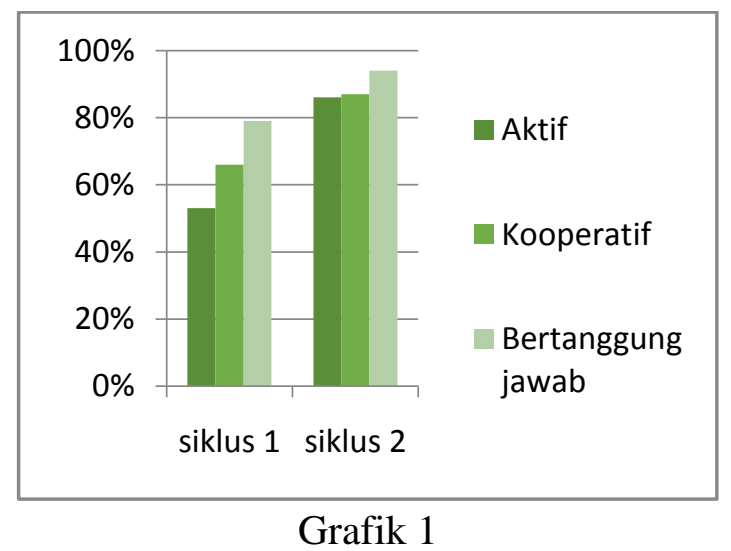

Prosentase Sikap belajar siswa dalam Menulis bahasa Inggris dengan Kegiatan pembiasaan sehari-hari pada siklus 1 dan 2

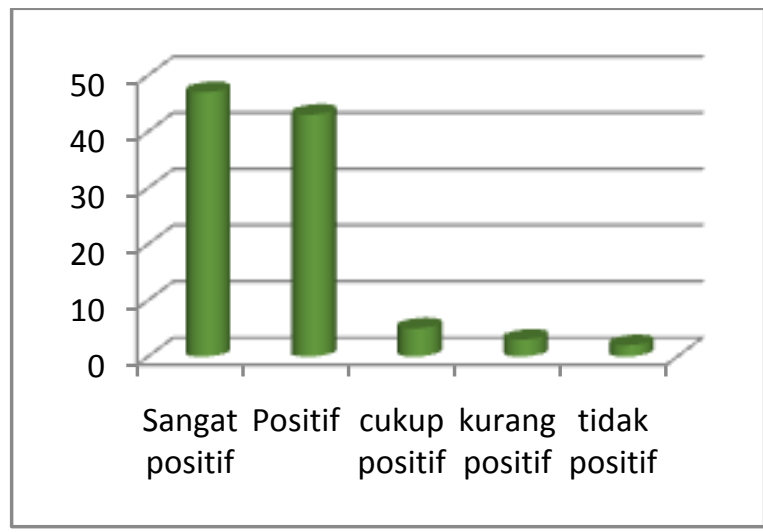

Grafik 2

Prosentase respon siswa dalam proses pembelajaran bahasa Inggris dengan lesson study 


\section{PEMBAHASAN}

Berdasarkan rumusan masalah penelitian, tujuan penelitian ini adalah untuk mengetahui sikap, pengetahuan dan ketrampilan siswa dalam menulis bahasa Inggris melalui lesson studyteks Kegiatan pembiasaan sehari-hari. Dari hasil tes awal dapat disampaikan bahwa kemampuan siswa kelas VII SMP seni Ukir Tangeb dalam menyusun masih rendah. Kemudian dilaksanakan penenlitian dengan menggunakan model rekontruksi lesson studydengan empat tahapan, yaitu : perencanaan, pelaksanaan, pengamatan dan perenungan. Di siklus 1, kemampuan siswa mulai meningkat dengan jumlah total nilai 2654 dan rata-rata 70 , median 72 dan mode 72. Dari data di atas dapat diketahui hanya 19\% siswa telah mencapai ketuntasan minimal, yaitu: 75. Dari rentangan PAP prestasi belajar siswa yang mencapai kreteria sedang sebanyak 33 orang sedangkan yang kretaeria kurang sebanyak 5 orang. Dari sikap belajar siswa dapat diketahui sebanyak 20 siswa (53\%) aktif, $25(66 \%)$ siswa yang kooperatif dan siswa bertanggung jawab sebanyak 30 siswa (79\%). Dari hasil ini dilaksanakan refleksi dengan memberikan latihan tambahan bagi siswa yang kurang dan pengayaan bagi yang kemampuannya sedang. Untuk sikap, diberikan motivasi,dan pendekatan pemodelan. Pada siklus 2 perubahan sikap belajar siswa mulai mununjukan peningkatan yang signifikan karena pesan moral dalam teks Kegiatan pembiasaan sehari-hari mempengaruhi kepercayaan diri mereka sehingga kesadaran belajar mereka meningkat. Kemampuan siswa pada siklus 2 meningkat dengan jumlah total nilai 3045 dan rata-rata 80,2, median 80 dan mode 80 . Dari data di atas dapat diketahui hanya $81 \%$ siswa telah mencapai ketuntasan minimal, yaitu: 75. Dari rentangan PAP prestasi belajar siswa yang mencapai kreteria tinggi sebanyak 21 orang sedangkan yang kreteria sedang sebanyak 17 orang. Dari sikap belajar siswa dapat diketahui sebanyak 30 siswa $(86 \%)$ aktif, 33 (87\%) siswa yang kooperatif dan siswa bertanggung jawab sebanyak 36 siswa (94\%). Dari hasil ini dapat dikatakan bahwa kemampuan siswa kelas VII SMP Seni Ukir Tangeb dalam sikap belajar, pengetahuan dan ketrampilan menulis bahasa Inggris dalam kategori tinggi dan sikap membudaya diatas $50 \%$.

\section{KESIMPULAN DAN SARAN}

Berdasarkan hasil pengamatan, tindakan dan refleksi tindakan, dapat disimpulkan bahwa Berdasarkan hasil pengamatan, tindakan dan refleksi tindakan, dapat disimpulkan bahwa model pembelajaran melalui lesson studysangat efektif dalam meningkatkan kemampuan menulis bahasa Inggris siswa kelas VII SMP seni Ukir Tangeb dan sikap belajar mereka lebih berkarakter. Untuk kemajuan dan kelangsungan kualitas pendidikan salah satunya adalah unsur sikap belajar, maka ada beberapa saran yang ditujukan untukinstitusi pendidikan, guru-guru bahasa Inggris, siswa dan peneliti lainnya. Bagi institusi pendidikan disarankan untuk memantau dan meningkatkan penggunaan soal-soal yang otentik sehingga dapat tercermin dalam dampak dari hasil belajar. Guru disarankan agar meningkatkan kemampuan mereka dalam memberikan pemodelan sikap dan pengalaman belajar yang bermakna .

\section{DAFTAR PUSTAKA}

Azwar, Saifuddin. (1997). Reliabilitas dan Validitas. Yogyakarta : Pustaka Pelajar Aminah 
Aminah, N.S. (2012). Dasar- Dasar Pengukuran dan Statistik pada Pembelajaran Fisika. Surakarta : UNS Press

Djemari Mardapi. (2008). Tehnik Penyusunan Instrumen Tes dan Non Tes. Yogyakarta:Mitra Cendekia Press.

Ekawati, Estina (2011). Pengembangan Instrumen Penilaian Pembelajaran MatematikaDasar. Yogyakarta : Kementerian Pendidikan Nasional

Mundilarto. (2010). Penilaian Hasil Belajar Fisika. Jogjakarta : P2IS FMIPA UNY

Suharsimi Arikunto. (2005). Dasar- Dasar Evaluasi Pendidikan. Jakarta: Bumi Aksara.
Supardi. (2008). Pengaruh Bentuk Tes Formatif dan Kecerdasan Emosional terhadapHasil Belajar Matematika. Ilmiah Faktor Eksakta I (2), 18 - 32.

Yamtinah, Sri. (2009). Evaluasi Proses dan Hasil Belajar Kimia. UNS Press : Surakarta

Richards, Jack C. and Renandya, Willy A. (2002). Methodology in Language Teaching: An Anthology of Current Practice. New York: Cambridge University Press

.Richards, Jack C. and Rodgers, Theodore S. (2001). Approaches and Methods in Language Teaching (Second Edition). New York: Cambridge University Press.

Sugiyono. (2012). Metode Penelitian Administrasi. Bandung: Alfabeta. 